\title{
Online University Teaching During and After the Covid-19 Crisis: Refocusing Teacher Presence and Learning Activity
}

\section{Chrysi Rapanta ${ }^{1}$ (D) $\cdot$ Luca Botturi $^{2} \cdot$ Peter Goodyear $^{3} \cdot$ Lourdes Guàrdia $^{4}$. Marguerite Koole 5}

Published online: 7 July 2020

(C) Springer Nature Switzerland AG 2020

\begin{abstract}
The Covid-19 pandemic has raised significant challenges for the higher education community worldwide. A particular challenge has been the urgent and unexpected request for previously face-to-face university courses to be taught online. Online teaching and learning imply a certain pedagogical content knowledge (PCK), mainly related to designing and organising for better learning experiences and creating distinctive learning environments, with the help of digital technologies. With this article, we provide some expert insights into this online-learning-related PCK, with the goal of helping non-expert university teachers (i.e. those who have little experience with online learning) to navigate in these challenging times. Our findings point at the design of learning activities with certain characteristics, the combination of three types of presence (social, cognitive and facilitatory) and the need for adapting assessment to the new learning requirements. We end with a reflection on how responding to a crisis (as best we can) may precipitate enhanced teaching and learning practices in the postdigital era.
\end{abstract}

Keywords Online teaching · Emergency situation · Covid-19 · Higher education · Pedagogical content knowledge $\cdot$ Instructional design

Chrysi Rapanta

crapanta@fcsh.unl.pt

1 Faculty of Social Sciences and Humanities, Universidade Nova de Lisboa, Avenida de Berna 26, 1069061 Lisbon, Portugal

2 University of Applied Sciences and Arts of Southern Switzerland, Lugano, Switzerland

3 The University of Sydney, Sydney, Australia

4 Universitat Oberta de Catalunya, Barcelona, Spain

5 University of Saskatchewan, Saskatoon, Canada 


\section{Introduction}

The urgent imperative to 'move online', caused by the recent Covid-19 pandemic (World Health Organization, n.d.), has added to the stresses and workloads experienced by university faculty and staff who were already struggling to balance teaching, research and service obligations, not to mention the work-life balance (Houston, Meyer and Paewai 2006; Houlden and Veletsianos 2020). Teaching staff of all backgrounds and ages have had to prepare and deliver their classes from home, with all the practical and technical challenges this entails, and often without proper technical support (Hodges et al. 2020). On top of that, a significant challenge for university teachers has been their lack of the pedagogical content knowledge (PCK) (Shulman 1987) needed for teaching online (Angeli and Valanides 2005; Kali, Goodyear and Markauskaite 2011; Ching, Hsu and Baldwin 2018). Such PCK includes technical and administrative aspects of teaching online (e.g. respectively, using platforms and tools and organizing workflows). More significantly, it includes the pedagogical foundations and knowledge of principles needed to design for, and facilitate, meaningful online learning experiences.

The present article focuses on the pedagogical preparedness of university teachers with no or little experience in online teaching. As recent studies have shown (e.g. Ocak 2011; Ching et al. 2018), some of the main difficulties reported by university teachers with respect to web-based courses arise from the complexity of the instructional situation and shortcomings in planning and organisation. The Covid-19 crisis has brought forth a plethora of advice aimed at teachers (Bates 2020). Much of this advice focuses on tools and materials that teachers can use to replace their face-to-face classes. In addition, teachers have been offered hundreds of 'tips and tricks', mostly without the contextualizing knowledge needed to judge which teaching tactic is likely to work where. Against this background, we have distilled some broader-based pedagogical guidance for teachers and those supporting them. The guidance we offer is based on research and years of experience in online learning and teaching-lessons learned in more 'normal' times but still applicable now.

\section{Literature Review}

The term 'online learning' is widely used but with a variety of meanings. For the purposes of this article, online learning refers to learning that is mediated by the Internet. It is wider than 'networked learning'; while networked learning focuses on human-human connections (Banks et al. 2003; De Laat et al. 2007), online learning lacks such specificity. It is narrower than 'eLearning' and 'digital education' which include the full range of digital tools and resources, not just the Internet and a focus on digital competences development. In addition, online learning does not have the in-built claim to improvement that makes 'technology-enhanced learning' (TEL) (Laurillard and Masterman 2010; Kirkwood and Price 2014) a problematic phrase (Bayne 2015). In our postdigital reality, one can argue that 'online' is ceasing to be a helpful descriptor for students' actual experiences (Fawns 2019), especially in the rich parts of the world, where Internet-connected devices are in such regular use, and the boundaries between learning and other strands of activity in everyday life have become so soft. However, 
the same cannot yet be said for 'online teaching' which comprises intentional support for other people's learning, mediated by the Internet. The rapid closing-off of face-toface educational work, in response to the Covid-19 pandemic, gave teachers a strong sense of the difference between online teaching and their other modes of operation. Experientially, online teaching is a recognisable category of working practices for many teachers (Goodyear 2002; Gonzalez 2009; Nilson and Goodson 2017).

For our purposes, online learning refers to a type of teaching and learning situation in which (1) the learner is at a distance from the tutor/instructor, (2) the learner uses some form of technology to access the learning materials, (3) the learner uses technology to interact with the tutor/instructor and with other learners and (4) some kind of support is provided to learners (Anderson 2011a). Much of teaching and learning in an online environment is similar to teaching and learning in any other formal educational context (Anderson 2011b). Online learning and teaching involve a diverse array of tools, resources, pedagogical approaches, roles, organizational arrangements and forms of interaction, monitoring and support - with many possible combinations of substitution and integration (Bates and Poole, 2003; Bullen and Janes 2007; Bach, Haynes and Smith 2007). Within this cornucopia of options, 'the capacity for shifting the time and place of the educational interaction' (Anderson 2011b: 344) stands out as a valued source of flexibility. From a postdigital point of view, online education has blurred boundaries between material, digital and human experience (Fawns 2019). In making the most of the opportunities afforded by online learning environments, instructional design and organization play an essential role (Anderson et al. 2001).

Instructional design (ID) and learning design (LD) can be characterized as 'a process, or series of suggested steps, that teachers can use to plan, implement, and evaluate their instruction' (Carr-Chellman 2016: xiv). Like any design process, ID and LD involve decision-making and problem-solving (Tennyson and Breuer 2010). They involve choice of strategies for creating particular products, e.g. lesson plans or instructional materials, as well as the implementation and management of the overall design process (Richey, Klein and Tracey 2011). Teachers as designers have to address both product-oriented and process-oriented aspects of strategic planning (Goodyear 2015). According to Bates (2019: 167), a good quality design is associated with 'clear learning objectives, carefully structured content, controlled workloads for faculty and students, integrated media, relevant student activities, and assessment strongly tied to desired learning outcomes'.

In face-to-face teaching, ID and LD theories and models are usually implicit in the decision-making processes used by expert teachers (Moallem 1998). However, when it comes to using online learning technologies as a main or the only means of teaching, the explicit use of some type of design process is necessary (Tennyson and Schott 2010). This is especially the case when a team is involved in developing and implementing an online course: coordinated action between different professionals needs a shared design approach (Botturi and Del Percio 2007). Design approaches for online learning have been operationalised in a variety of systems and models, drawing on a range of design principles. This differentiation also accounts for some terminological preferences, with the language of ID currently being used when the focus is on instruction and when a high degree of normativity applies, and the language of LD (Sims 2015) or techno-pedagogical design (e.g., Winters and Mor 2008) being used when the focus is more on learner activities and responsiveness to context. 
Regardless of the approach (ID, LD, or techno-pedagogical), what is important, in the end, is that instructors work towards 'designing conditions under which learners have a better chance to learn' (Parchoma et al. 2019: 13).

Under this teaching as 'design for learning' perspective (Goodyear and Dimitriadis 2013), teachers act as both constructors and actors. On the one hand, they need to design the tasks, environments and resources that help students learn. On the other hand, they must enact the designed lesson plan, shifting nimbly between roles as appropriate: e.g. as an orchestrator, a facilitator, etc. Anderson et al. (2001) refer to this complex mix of instructional roles as 'teaching presence', which includes learning design and organization, facilitating discourse and direct instruction. Of these three components of teaching presence, the one related to learning design and organization is probably the most problematic as design-related teacher presence must be mediated and manifest throughout the course design and not only during its 'delivery' (Guàrdia, Maina and Sangrà 2013). It is also understudied as a PCK related to the teachers themselves because many online courses have in the past been designed by learning design specialists (i.e. instructional designers) and delivered/enacted by tutors-teachers.

In the Covid-19 emergency situation, teachers have, almost overnight, been asked to become both designers and tutors, using tools which few have fluently mastered. This paper sheds some light on pedagogical knowledge that new online teachers need, in order to design worthwhile learning activities and flourish in this unfamiliar space. Our goal is to make explicit some main aspects of the online teaching expertise, akin to be transferred in the pedagogical practice of any educators, with or without experience in teaching remotely. We close the paper with a postdiscussion in which we reflect philosophically on our methodology and co-authorship strategy. Ultimately, we conclude that the importance of designing effective learning environments rests not only upon the shoulders of faculty but also upon institutions of higher education more generally in the form of support (funding) for faculty professional development.

\section{Method and Findings}

The method used for this exploratory study was expert interviews (Bogner, Littig and Menz 2009). Experts, when seen as 'crystallization points for practical insider knowledge' (Bogner et al. 2009: 2) can provide useful insights on newly emerging topics: insights which are not so easily or quickly obtained through other means. The forced digitalisation of teaching and learning during the Covid-19 pandemic is clearly one of those emerging topics (Jandrić 2020).

The participants were selected according to their proven expertise and deep experience in the field of online teaching and learning. Three main criteria were applied: (1) Research expertise, more than 1000 citations on Google Scholar, with online teaching and learning innovation forming a major part of their research; (2) Online teaching experience, more than a decade of working as an online teacher; and (3) Experience with different national education systems. The selected experts currently work in Switzerland, Australia, Spain and Canada. They have direct experience of working with educators from continental Europe, the UK, North America and Australasia, as well as with educators from many countries in the Global South. These experts are also co-authors of the paper, and their answers to the interview questions are co-presented as 
if they formed part of the same discussion panel. The interviews included five questions and were administered by e-mail, after the goal of the research was explained to the participants. The five questions were as follows:

1. In what aspects do you think online learning design and delivery is different than face-to-face teaching and learning?

2. What do you think makes online teaching and learning successful?

3. What would you say to non-expert colleagues who follow a materials-based approach to online teaching, e.g. sharing materials with students or asking them to produce materials?

4. What would you say to colleagues who follow a tools-based approach to online teaching, i.e. the idea that tools such as videoconferencing or text-based discussion boards are the key features of online learning?

5. What are some effective ways of monitoring students' engagement and learning during online courses? How can they inform assessment?

The choice of the questions was based on some of the hidden misalignments between online education and emergency remote teaching (Hodges et al. 2020). For example, online education pre-supposes an existing organizational infrastructure, serving the purposes of online teaching and learning. In contrast, the emergency remote teaching required by Covid-19 has often been improvised rapidly, without guaranteed or appropriate infrastructural support. Given this lack of infrastructure, much of the early advice and support for non-expert online teachers has focused on the technological tools available in each institution and considered adequate to support the switch. However, this 'toolsbased' approach (question 4) does not give many pedagogical hints on how, when, and why to use each of the tools. Similarly, many non-expert online teachers opted to focus on the materials/resources they would use anyway to teach their course contents, independently of its format being face-to-face or online. Again, this 'materials-based' approach (question 3) is only half-complete, given that it pays insufficient attention to contextualisation and mediation. Although technologies and resources are necessary ingredients for online teaching (Anderson 2011a), teachers' support for students, including through monitoring their learning processes, is what makes teaching effective- as with face-to-face situations. However, due to the lack of a common, widely understood, pedagogical framework for online teaching and learning (Picciano 2017), it is not clear what additional pedagogical dimensions need to be considered in an online situation.

Each expert replied to the questions by responding only to the interviewer (first author). Only after the first author wrote the first version of the paper, did the other authors have an opportunity to read each other's answers and to contribute to weaving them together into the present article. In the following section, we present the experts' responses to the five questions without accompanying comments. We highlight and discuss some emerging themes in the last section of the paper. We invite the reader to identify themes of their own, as they work through the answers. The experts' responses are presented as received, with only minor language edits and layout changes. These changes were checked and approved by each of the experts. The discussion synthesises the main common aspects that emerged from the set of answers. This was drafted by the first author as the 'panel' organizer, and then revisions and contributions from all the experts were integrated with it. 


\section{Question 1: In What Aspects Do You Think Online Learning Design and Delivery Is Different than Face-to-Face Teaching and Learning?}

\section{Luca Botturi (E1)}

As for content, online learning is based more on materials (readings, videos, exercises, etc.) than on direct personal interactions (discussions, presentations, etc.). On the one hand, this offers the opportunity to integrate more media (video, images, audio, etc.), but teachers should produce or find good materials and be able to leverage on them; on the other hand, it requires students to be more autonomous in reading (meaning 'reading' all media). As for guidance, online learning relies on mediated communications, either synchronous or asynchronous. In both cases, indications from teachers should be spelled out very clearly and carefully, as progressive refinements through interactions are hardly possible. Again, students should be more autonomous in both understanding guidance indications and working with no micro-scaffolding. In light of the need for good communication and attempts to encourage more student autonomy, online teaching requires more careful design. Also, the design happens more before the course than during the course. This implies a different way of organizing the teacher's work. If I were to name another point, I'd mention evaluation: finding fixes to conduct classic large-scale assessments (written exams, interviews) online is frustrating. Online evaluation and certification require re-thinking evaluation from scratch (e.g. including continuous evaluation or separating formative and summative evaluations), and in some cases, this also implies fine-tuning the course differently.

\section{Peter Goodyear (E2)}

There is such diversity in online teaching and learning practices and in face-to-face teaching and learning practices that it is difficult, and perhaps a little dangerous, to make sharp contrasts between them. Each is quite heterogeneous. For example, using a pre-recorded online lecture without a live connection to your students is very different from holding a live online class using videoconference or chat. Similarly, a one-to-one face-to-face tutorial is very different from giving a face-to-face lecture to a class with hundreds of students. With that caveat in mind, I would offer the following suggestions to university teachers who have had to adapt very quickly to teaching online:

- Try to open up extra communication channels so that you can (a) reliably get key messages to your students; (b) be very alert to what they need (e.g. what they are finding difficult about studying this way; what they need more or less of) and be sure to keep asking and listening because their needs, and their ability to articulate their needs, will evolve; and (c) make it easy for students to talk to each other, share experiences, tips, etc. (make at least one channel or chatroom private to the students - no teacher access). The underlying point here is that conventional face-to-face teaching arrangements often provide opportunities for communication (especially between students) that we, as teachers, do not always recognise and which may disappear with the move to online, e.g. students in face-to-face lectures tend to read subtle cues to get a sense of whether a new idea they are finding difficult is also proving difficult for their peers (e.g. 'Is it just me who's stupid, or is this idea really complicated?'). Students' spontaneous 
conversations before and after class are an underappreciated strength of face-to-face/oncampus education. They supplement the formal or overt curriculum.

- Use this as an opportunity to shift further along the continuum from teacher/subjectmatter centred to student/activity-centred educational methods. Find ways of shifting your attention from (your) coverage of prescribed 'content' so that you can focus sharply on what your students are actually doing. Their activity is always the key to successful or unsuccessful learning (whether in face-to-face or online situations). In conventional face-to-face lectures, students' activity often consists of little more than taking notes and asking questions. It is actually easier to organize a much wider array of activities for them in a novel (online) situation than in wellestablished face-to-face teaching situations (where practices are engrained and harder to modify). But to do this sustainably, you have to think carefully about designing good tasks and ensuring that students understand what they are meant to do and why. In turn, this helps them become better at regulating their own learning activities. Moreover, while they are getting on with a task you have set for them, you can clear some time to think about the next tasks/activities.

- Simplify; cut back expectations; help reduce anxiety. Students will simultaneously be having to adapt to new ways of teaching and learning and deal with all the logistical complications and emotional stress of the pandemic and its associated lock down. In familiar face-to-face teaching-learning situations, we rely on many barely-perceived supports, cues, prompts, etc. In other words, the physical world provides a variety of 'structuring resources' which are missed once they are gone. Lighten the load, ditch nonessential parts of the syllabus. You can always build things back up later, if you have over-simplified.

\section{Lourdes Guàrdia (E3)}

The design of an online course is a strongly student-centred approach. The teacher role is more focused on facilitation and on the student support regarding competences development. The student role is to be the owner of his/her learning process and being more autonomous. Online learning allows self-paced learning and reflection. Learners can review the learning resources and improve activities multiple times, and teachers can monitor their progress following all the process. It is more flexible. In this sense, a student-centred approach is more focused on evidence-based learning and continuous assessment. The face-to-face model is still too much teacher-centred. Another benefit of online learning as compared to face-to-face is the openness of the approach, searching, especially in this pandemic Covid-19 scenario, the opportunity of offering an effective education, regarding inclusiveness, ensuring every citizen has an opportunity to develop their talents and to feel part of a shared future. Complicated economic scenarios are coming; therefore, an online model that could cover training needs for all citizens should be ready to solve emerging and new problems.

\section{Marguerite Koole (E4)}

Having been involved in the design of online and distance learning for nearly 20 years, three key differences between face-to-face and online learning include (1) space and presence, (2) self-presentation, and (3) interaction. 
Conceptions of space and social presence become salient as we shift modalities. Technology has a way of altering time and space, metaphorically compressing them. In face-to-face classrooms, teachers and learners are physically and temporally co-present (synchronous). In online learning, on the other hand, learners may be physically distant but temporally co-present (synchronous; audio or video conferencing), or they may be physically and temporally distant (asynchronous; ground mail, text messaging, text-based conferencing or pre-recorded audio or video sharing).

The way in which we present ourselves when using different technologies may be vastly different. For example, when engaging in text-based communications, a learner may spend more time crafting and honing the quality of their written expression so as to appear more literate and/or knowledgeable. Similarly, when recording and editing a video presentation, a learner may spend time editing with a special emphasis on the characteristics they wish to convey - that of a techno-wizard or a highly articulate speaker, for example. While asynchronous tools permit more flexibility in thinking and response time as well as time to craft one's persona, synchronous technologies might allow a seemingly more authentic performance of self because it occurs in real time with less contrivance. Regardless, the more cues over time, the more accurately we can interpret others' behaviours and identities.

In absence of the conversations and behavioural cues we are used to in face-to-face classrooms, we look towards different interaction patterns online. As per Moore (1991), the main forms of interaction in distance learning include teacher-student, studentstudent, and student-content. Other researchers later added student-interface, contentcontent, teacher-teacher and teacher-content interaction (e.g. Anderson 2003). Online teaching and learning require careful consideration for how technology(-ies) can facilitate the types of interaction we seek.

\section{Question 2: What Do You Think Makes Online Teaching and Learning Successful?}

\section{Luca Botturi (E1)}

From the point of view of the students, the most important things are accessibility (having the proper devices/connection/software) and autonomy (i.e. ability to set goals, manage time, avoid distractions). But I think the focus here is on teachers, so I mention three design- and teaching-related elements: student-centred design, social activity and peer collaboration.

Successful online learning requires student-centered design, i.e. carefully thinking about what students will actually have to do to learn. If we focus on content, we end up with poor and cheap video or multimedia production, which will not achieve its goal. If we focus on what learners will do, we put them in motion and have an opportunity to help them actually learn. Of course, among what students should do, we can include listening to a podcast, reading a text or watching a video. This entails conducting a proper task analysis, i.e. thinking to the practicalities. For example, we should avoid sending a 30-page text if students cannot easily print. We should also consider a program-wide perspective especially in this emergency: we should help students find a balance with their global situation-e.g. allowing flexible time or excluding $6 \mathrm{~h}$ in a row in videoconference. 
Successful online learning means not feeling alone and not forgetting that learning is social: we learn from others and with others, even if at a distance. The way a teacher can be present online is not talking to the camera during videoconference sessions but providing timely and accurate feedback, both on questions and as evaluations. Actually, online learning provides more opportunities to devote attention to the correction of individual work. And we know that individualized feedback is a powerful learning engine.

For the same reason, a successful online course (especially if it spans over multiple weeks) promotes peer collaboration. Even at distance, students are not alone and have means to establish both formal and informal contacts. From the teacher perspective, this means stimulating collaboration such as through group assignments or perhaps by introducing peer-teaching or peer-assessment. In today's situation, collaboration may also help achieve a more stable personal balance.

\section{Peter Goodyear (E2)}

Ensuring success in online learning involves excellent communications skills, careful design and active involvement of the learners. Clear communication with students implies clarity over expectations - well explained tasks with wellexplained rationales (what they need to do, and why you are asking them to do it). Listening carefully to what students are saying about their experiences, what is working well for them and what is not, is also an important part of good communication. Teachers should also dedicate a sufficient amount of time to careful design, through shifting their time 'upstream', as careful design pays off. Finally, they should allow for, and encourage, student co-design and/or co-configuration of learning activities and environments. Students will modify tasks teachers set for them and they will reconfigure learning environments, recommended tools and resources, working relationships etc. So, teachers must not assume that what they design and specify will be followed $100 \%$ by the students, and this is totally fine as students' engagement in the design and execution of learning tasks functions positively towards their self-regulation.

\section{Lourdes Guàrdia (E3)}

I would like to draw upon here a project named FUTURA: Next Generation Pedagogy: IDEAS for Online and Blended Higher Education (Guàrdia et al. 2016). I led FUTURA 4 years ago, about the future of the universities taking in consideration the ICT advantages and the growing interest for blended and online models. More than a hundred successful cases, focus groups and interviews with online education and educational technologist experts were addressed. The contribution of the IDEAS framework was five signposts on the roadmap of innovative approaches to teaching, which point to next-generation pedagogy for blended and online educational models, as summarized below (Guàrdia and Maina 2018):

- Intelligent pedagogy is an approach to teaching in which technology is used to enhance the learning experience. Examples include using learning analytics to support course leaders in curriculum design decisions as well as to help students 
manage their learning and the creative use of technologies such as virtual and augmented reality for learning and teaching.

- Distributed pedagogy refers to shared or distributed ownership of different elements of the learning journey by different stakeholders in the process. It includes, at the one end of the spectrum, collaborative partnerships between institutions, and at the other, a deliberate separation of services to allow learners to select different aspects of their learning experience from a marketplace of potentially competing providers.

- Engaging pedagogy is an approach to curriculum design and delivery in which learners are encouraged to actively participate in the learning process. Related practices include supporting students to develop portfolios that have relevance for them outside of the classroom, involving the learners in producing content both for peers and for the wider public.

- Agile pedagogy refers to flexibility and customisation of the curriculum and the student experience. It includes personalised learning pathways and individualised support for learners, recognition of prior, non-formal learning achievements in order to widen participation and fast track learners through programmes, responsiveness of institutions and systems to learners' needs, and support for virtual mobility of students and internationalisation of the curriculum.

- Situated pedagogy encompasses the idea of contextualisation of learning and emphasises the need for curricula with real-world relevance. It expands workrelated learning opportunities for students and supports them in identifying and addressing big issues in industry, government and society through project- and problem-based learning. In situated pedagogy, learning and assessment are contextualised according to students' professional and personal goals.

\section{Marguerite Koole (E4)}

There are a variety of ways in which instructors can help make the online learning experience more satisfying and effective: (1) effective planning, (2) learner preparation, and (3) enhanced interaction. To start, effective planning includes chunking and pacing content, designing a schedule of assignment due dates and setting a regular schedule for activities. It is advisable to acquire some knowledge of the learners' needs, aptitudes and abilities. Hosting a welcome forum or activity can help instructors get to know the learners and help the class establish rapport. Keeping in mind the different possible types of interaction, an instructor can consider in advance how learners will interact with, say, a reading, a video or a podcast. Drawing upon their knowledge of the learners' needs and aptitudes, the instructor can construct guiding questions and discussion prompts to encourage probing, interrogating, critiquing and relating to content and other learners.

Learner preparation refers to learners preparing themselves to engage in online learning. A week or two prior to the start date, an instructor can send a welcome message indicating the structure of the course, types of assignments, tips for success and some indicators as to the metacognitive and self-regulation skills needed (such as levels of autonomy and/or participation). Once the learners know what to expect and feel comfortable, it is possible to facilitate the development of strong, positive relationships with others in online settings (Henderson and Gilding 2004). Online, the 
challenge for learners and instructors becomes one of noticing and interpreting cues in order to get to know others. Accessing more cues can be done through the use of rich media, synchronous interaction or frequency of interaction. However, there is a tradeoff: opportunities to interact through rich media and high frequency interaction may reduce flexibility and require greater bandwidth - both of which may create accessibility challenges for some learners.

\section{Question 3: What Would You Say to Non-expert Colleagues Who Follow a Materials-Based Approach to Online Teaching, e.g. Sharing Materials with Students or Asking Them to Produce Materials?}

\section{Luca Botturi (E1)}

When in class, good teachers are mediators between the content and the learners. This means creating pathways so that everyone can learn, as each one of us is different in cognition, motivation, self-esteem, etc. When we are online, materials alone cannot provide the mediation. For example, we can hinder students with specific learning preferences (e.g. visual or aural) because we just rely on texts, or we cannot provide an alternative path to knowledge for those who do not get it the first time- which in class can happen by telling a new example. More deeply, materials alone do not provide any room for embodiment. When we teach, in some way we are what we teach; we provide a living model of how what we teach gets real. Materials alone cannot do it, if not only very indirectly (i.e. the teacher's personality emerges through his/her selection of materials).

Nonetheless, relying on good materials in online teaching is a key ingredient, as it is an effective way to present content accurately. Good materials are accurate in content, accessible to students and adequate to their level of autonomy; moreover, they should fit within the overall learning design through appropriate scaffolding. Some materials might be good because they stimulate reflection; others because they call to action and interaction; others because they present content clearly, etc. The same holds for students producing materials: it can make sense if framed within a complete course design.

\section{Peter Goodyear (E2)}

I am not sure I understand the concept here. My experience with successful online learning - as well as reading the literature - suggests that we always need a mixture of materials and communication. If a course is offered entirely through pre-prepared materials, with no dialogue or feedback or opportunity for the teacher(s) to adapt, then the risks of disaster are unacceptably high, and much student distress may be invisible.

\section{Lourdes Guàrdia (E3)}

Online learning cannot focus on content delivery that reproduces lecture-based, teacher-centred, transmissive face-to-face models. In my opinion, given that this scenario no longer makes sense for traditional education, it makes even less sense for an online 
learning model. A traditional face-to-face model relies more heavily on traditional lecture-style delivery of content and classroom-based learning activities. And in the online context active pedagogies supported by ICT are in the centre of the learning process and content with multiple formats are considered as a support but not as the main resource.

A learner-centred approach is a key issue in online learning models, but it does not eliminate the teacher. A learner-centred environment facilitates a more collaborative way for students to learn, and the teacher acts as a facilitator, providing feedback and answering questions when needed. The teacher should design meaningful learning activities, based on authentic learning, contextualizing learning situations as much as possible.

\section{Marguerite Koole (E4)}

The choice of a materials-based approach would depend very highly on the course objectives and assessment standards: what do the learners need to learn? For someone new to online teaching and learning, a materials-based approach can create challenges by shifting focus away from the process of learning towards end-products. Another issue that may arise if a learner lacks access to adequate bandwidth or the necessary software to access materials. For this reason, file types and file sizes require consideration as well as quick tests to verify if materials can be accessed on a wide variety of common devices and accessed with little cost.

\section{Question 4: What Would You Say to Colleagues Who Follow a Tools-Based Approach to Online Teaching, i.e. the Idea That Tools Such As Videoconferencing or Text-Based Discussion Boards Are the Key Features of Online Learning?}

\section{Luca Botturi (E1)}

Videoconference is another key ingredient in online learning - and we are lucky that video conferencing today is so affordable and accessible! Teaching through video conferencing is actually very challenging, as changing media means changing the communication patterns, and good teachers are most often poor video actors. In video conferencing, we have a poor attention curve, interactions are slow, there are many distractors (we are not 'at school'), and the overall timing should be different in order to be effective.

Video conferencing can be a powerful tool to engage in prepared live interaction situations (Q\&A, feedback, project reviews, etc.) but can hardly replace classroom teaching when this means lecturing. It is actually more flexible than being in class: we can have short sessions with small groups (e.g. for project review), talk for a few minutes with one student who has a question or ask students to work in groups, etc., but it is hardly effective with a larger group for longer periods.

\section{Peter Goodyear (E2)}

If by 'tools-based approach' you mean online as entirely through 'live teaching', then I think the danger is that teaching staff will burn out, students will be overloaded and 
opportunities will be missed for students to engage in valuable learning activities (synchronous, asynchronous, online, offline) that do not need a strong/live teacher presence. In other words, (combining questions 3 and 4) I think there is strong evidence to say that students benefit from a mix of activities - some of which depend on live teaching and teacher-led discussion and some of which do not need a live teacher presence — set tasks, using pre-prepared materials and/or student-generated materials, etc.

\section{Lourdes Guàrdia (E3)}

Well, this is a big challenge! Very often, institutions and educators start thinking on the tool first rather on the pedagogical issues. Tools are changing very fast, so if we are able to identify the pedagogical needs, the innovation opportunities, the quality issues required, the social demands and the advantages of the use of ICT, then, it does not matter which tool we will use to achieve all these aspects. The challenge is not their use in itself but that the pedagogical purpose should be justified identifying its benefits.

\section{Marguerite Koole (E4)}

For instructors taking a tools-based approach to online learning, the major concerns would include cost, privacy, computer requirements and necessary bandwidth. Some tools with free options, such as Zoom, have recently experienced a surge in popularity as the Covid-19 pandemic spread across the globe. Zoom is also currently in the news for privacy concerns (Hodge 2020) ranging from hacker intrusions ('Zoom-bombings') to information sharing with social media platforms and third-party analytics engines. It is, therefore, important to examine the business model of the tools. A 'free' tool, for example, may generate income through advertisement or sharing user data.

Depending on the tools selected, learners may also need to install software which may require varying amounts of bandwidth and hardware/software configurations as well as changes in security permissions to allow the software to operate (i.e. allowing access to files, cameras and microphones). Large downloads may be costly in locations where data fees are high. Canada, for example, has among the highest data rates in the world for mobile devices (Geist 2019). Because of the pandemic, learners cannot simply go to the local library or other public place to use free Internet service.

\section{Question 5: What Are Some Effective Ways of Monitoring Students' Engagement and Learning during Online Courses? How Can They Inform Assessment?}

\section{Luca Botturi (E1)}

One way is controlling the data on students' activities in the Learning Management System (LMS) used - the so-called learning analytics. While there is a vast literature on this, for a teacher, this means identifying key indicators and setting up a way to control them (most LMSs have tools for this). Key indicators can be downloading a text, posting to a forum, accessing the course at least once a week, etc. If these indicators are properly defined and communicated to students, they (or part of them) can be part of the evaluation (as elements of a continuing evaluation system, see above). 
Of course, the analytics provide just formal insights - useful but not complete (even if more accurate and detailed than attendance sheets in class). Another monitoring element is the quality of students' contributions. If a teacher plans specific moments of interaction (e.g. on a forum) s/he can assess the quality of students posts in terms of length, relevance, originality, etc. These elements as well can be communicated and can become part of the evaluation.

\section{Peter Goodyear (E2)}

It is important to monitor learner progress. Simple learning analytics data/traces (log ins, number and frequency of online contributions, etc.) can be very helpful in alerting you to students who are in danger of dropping out, getting lost, etc. If an instructor is designing sequences of tasks for students to engage in (individually, in groups or teams, etc.) then that, by its nature, provides you with another window into student engagement. An instructor can also ask learners to comment on course and task designs, resources available, quality of infrastructure and tools; this helps the instructor to fine-tune what is being offering, and it helps the learners get better at judging what they need. It also strengthens the relationship between teacher and students. Look at some of the core ideas in the 'students as partners' area for further inspiration.

\section{Lourdes Guàrdia (E3)}

The use of ICT can add value to the assessment process, both for teachers and students. Its use facilitates more continuous monitoring of learning experiences and processes. The management of personalized qualitative feedback, automatic feedback for receiving immediate responses, the use of diversified instruments and strategies of assessment (self, peer and group assessment), collecting data generated by the system and informing about the learning process is very useful for teachers and students, as learning analytics strategy, to support and scaffold learning at any time... so, these are some examples of the benefits of online assessment approach.

Using e-Assessment to enhance student learning and evidence learning outcomes is very challenging. ICT has affected how curricula might be designed and delivered through an online environment, but new approaches to assessment are still needed. User-centred approaches to assessment involving authentic assessment tasks should be implemented. In this sense, technology is progressing quite fast and supporting simulations, virtual and augmented reality, and making easier the use of ICT for teachers and students (Crisp, Guàrdia and Hillier 2016).

Continuous assessment is a key issue in an online education model. Collecting information through all the learning process is crucial and should be done presenting evidence (artefacts, pieces of work, explanations of experiences, reflections about student practices, challenges and achievements). This evidence can be measured using competence performance criteria displayed through different kind of instruments. The use of ePortfolios, for example, is one of the strategies that is highly recommended for online education. It allows the students to collect evidence of their learning and reflect about them and the teacher to facilitate the monitoring of the process. 


\section{Marguerite Koole (E4)}

Active instructor presence and ongoing communication provides the learners with a sense of interaction and relationship in online learning. Regularly monitoring and participating in discussion forums and synchronous discussions can also help the instructor assess comprehension and performance. Indeed, log files in learning management systems can be useful in determining course access rates, frequency and duration of interaction with particular content and course tools and assignment submissions. When a student is inactive, or lagging behind, an instructor can send an email or make a phone call to open communications about time management, misunderstandings and comprehension of course content and processes.

\section{Discussion}

In the effort to ensure access to and continuity of education, faculty have valiantly moved ahead with online teaching. Now that the initial shock has passed, it is a good time to reconsider how we might better invest time and resources in course design. We summarise and discuss the expert contributions under three broad headings: learning design, teacher presence and assessment. We also offer suggestions for follow-up reading.

\section{Learning Design}

What all four experts focus on as a prime 'piece' of pedagogical knowledge (Kali et al. 2011) is the careful design of activities. According to Carr-Chellman and Duchastel (2000: 233), 'the essence of an online course is the organization of learning activities that enable the student to reach certain learning outcomes.' While there is no unique recipe, these activities or tasks should be based on a mix of design approaches (synchronous, asynchronous, online, offline), be described and communicated in an accurate and clear manner, have an adequate level of difficulty for students' capabilities and expectations, be related to authentic contexts to increase students' engagement and be accessible to everyone - taking into consideration the various practicalities that lie behind, for example, having a stable Internet connection, printing facilities or access to resources.

Figure 1 presents the main components of an online teaching activity aiming at a concrete learning goal, as emerged from the four interviews. The main components of a learning activity include as follows:

- the context (e.g. the learner's goals),

- the tools and resources used (e.g. communication channels between the learners and the teachers or among the learners),

- the concrete tasks (e.g. encouraging peer collaboration), and

- the relations between the three (e.g. how interactive the tools are, how self-paced/ individual the tasks or how necessary it is for the teacher to mediate the use of resources). 
All these characteristics define the type and nature of the designed learning situation. In addition, this overarching learning triangle is rooted in the roles assigned to or adopted by both teachers and learners, the assessment types and nature and the learning objectives pursued, which do not necessarily coincide with the pre-defined learning goals. A certain design flexibility based on a continuous and careful learner, task, tool and context analysis, which is in the heart of the learning activity, is required by the online teacher at all steps of the process (i.e. design, delivery and evaluation of learning).

\section{Teacher Presence}

A second emerging theme is teacher presence: how are teachers actually teaching their courses, e.g. establishing a relationship with their students?

Inspired by Anderson et al.'s (2001) understanding of teaching presence and how it can be re-conceived in the current Covid-19 situation in which educators are the designers, the tutors and the evaluators of the learning experience, a tripartite framework emerges from the interviews, with three main sub-presences of the teaching presence, namely:

- a cognitive presence, focusing on how teachers take into consideration students' preparedness to participate in the online learning experience,

- a social presence, referring to the social communication channels that teachers must open to maintain and possibly enhance the lost spontaneous student-student and student-teacher interaction, and

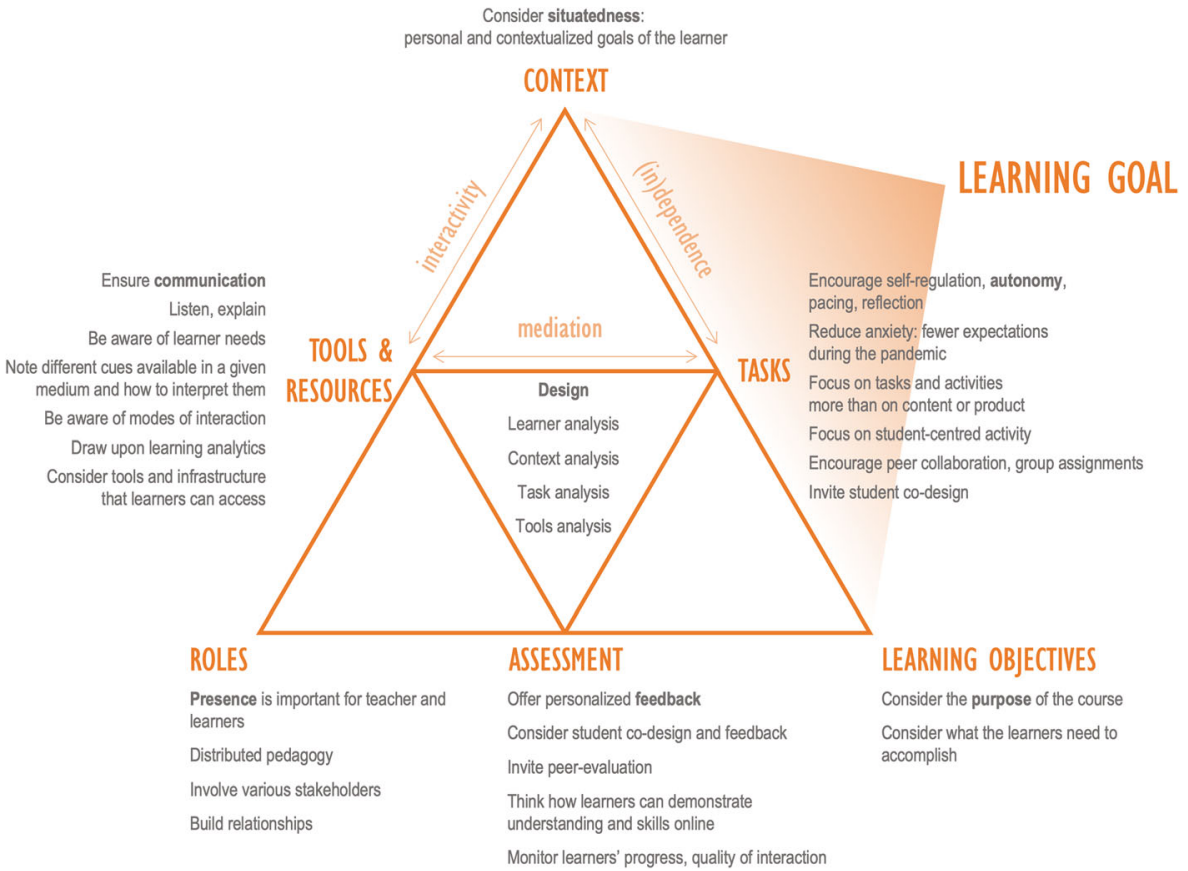

Fig. 1 Emerging aspects of the online learning activity focusing on teachers as the main actors 
- a facilitatory presence, embracing teachers' facilitatory discourse, direct instruction embodying tools/resources and mentoring activities.

\section{Assessment}

Assessment can possibly be considered the most challenging part of the transition to distance learning for an institution used to face-to-face oral or written exam, as the control shift towards the students makes it hardly possible to ensure that students are not cheating (Munoz and Mackay 2019).

All four experts agree that a continuous assessment model must be adopted, which agrees with the cognitive expectation of self-regulation, very important in online learning (Cho and Shen 2013). Self-regulation mainly refers to students' efforts 'to manage learning processes systematically oriented to achieve goals' (Cho and Shen 2013: 290). As the current emergency remote teaching (Hodges et al. 2020) situation invoked by the Covid-19 crisis is also new to the students, teachers must take into account the time and effort they need to regulate themselves in order to adapt to the new learning situation. One way of doing so, is to make self-regulation a part of the assessment, for example, through self-reflections or portfolios. Another, more general way is to propose self-paced, asynchronous activities (always within a pre-defined timeline) as part of the students' learning process and indicate clear ways of assessing students' participation.

Both approaches shift the focus onto students as responsible for their own learning, which is important also for avoiding teachers' burnout due to a continuous engagement in synchronous direct instruction. As teachers will probably devote more time than before to the design of the online learning activities, they must be proactive and distribute those activities over time (for example through assigning more asynchronous collaborative and individual work) and space (for example through dedicating time to mentor assessment as part of a videoconference, using the chat function or giving the opportunity to students to present the results of their self-regulated inquiries).

Garrison and Kanuka (2004) argued that thoughtfully designed blended learning can preserve and enhance the 'traditional values' of higher education. Fifteen years later, we might say the same for online teaching and learning: not just as an emergency remedy but as a way of enriching and extending the educational possibilities open to all universities. The affordances and opportunities provided by online learning environments - their capacity to be stimulating, inclusive and flexible (when designed appropriately) — must be given due consideration by programme coordinators in every student-centred higher education institution in the postdigital era. Experience with online learning will increase the readiness of both teachers and students for the postdigital era. Learning personalisation and flexible pathways can only be provided with a good course design that takes into consideration the full context of the teachers' and learners' digital-material-human encounters. To reiterate, if teachers invest time in designing learning activities that address learners' cognitive and social needs, better learning outcomes are possible. This design pedagogical knowledge is not limited to online teaching and learning but can permeate face-to-face contexts as well, further expanding educational benefits. 


\section{Postdiscussion}

This study was carried out some days after the lockdown of universities (and schools) took place as an emergency response to the Covid-19 pandemic. Due to the time constraints of carrying out research that is meaningful however rapid, we opted for a heuristic research method of relying on experts' viewpoints, which by no means can replace rigorous, systematic research following the scientific method of observation, hypothesis formulation, testing and interpretation. Still, heuristic methods are scientific as they allow for a certain degree of validity and reliability to be achieved. As Moustakas (1994: 18) explains: 'In heuristic investigations, verification is enhanced by returning to the research participants, sharing with them the meanings and essences of the phenomenon as derived from reflection on and analysis of the verbatim transcribed interviews and other material, and seeking their assessment for comprehensiveness and accuracy.'

This study's participants, i.e. the four online pedagogy experts, also functioned as co-researchers, following Moustakas' (1994) idea (1). Doing this, we secured a two-fold requisite of heuristic research: first, that their experiences in research and teaching were reported as authentically as possible given the final editing undergone; and second, that those experiences informed each other in a panel-like format, through which all four coresearchers were given equal access of commenting on, revising and re-writing every part of the article. This co-authorship model with the authors' original viewpoints remaining almost intact as part of the manuscript is also found in other written dialogic experiments such as Shor and Freire's (1987) Pedagogy for liberation, Matusov, Marjanonic-Shane and Gradovski's (2019) Dialogic pedagogy and polyphonic research art, Jandrić's (2017) Learning in the age of digital reason and the polyphonic article published as a continuation of Jandrić's book (Jandrić et al. 2019). This type of dialogic model of research, rooted in Bakhtin's (1986) dialogism, has several benefits as well as implications as discussed below.

The main benefit of collective research of any type is that it allows several voices to emerge, not only at the authoring stage, which is usually the case of multi-authored studies, but also and mainly at the data collection and discussion stages, which is where new theories can emerge. An example of such research is the recently developed method of duoethnography (Norris, Sawyer and Land 2012), which, as the authors' state, 'create(s) heteroglossia not only by collaborating together but also by juxtaposing and interacting with pedagogies of places and cultural artifacts' (14-15). This juxtaposition and interaction may allow for an authentic dialogue between researchers to take place. Even in the case of verbatim interviews and discussion upon them, as in the present study, authors had the opportunity to act, through uttering their own responses to the prime researcher's questions, and to re-act to each other's utterances, through the collective revision process which always took several rounds until everyone equally participated. Such constructive dialogue, mediated by technologies (several rounds of collective e-mails in our case), can be considered as a postdigital dialogue per se, not because of its contents (i.e. talking about the future of online education in the postdigital era) but because of its goal: to overcome physical barriers and to 'meet' intellectually with the use of (and because of) online digital means.

Certainly, this collective enterprise is not without its implications, mainly regarding the critical and policy-making aspects of research. From a critical research and pedagogy perspective, there lies the paradox of critical versus reflective subjectivity, which 
needs to be acknowledged here, as the prime researcher, and the four co-researchers invited by her may hold similar viewpoints on what effective online pedagogy is or looks like. However, this risk inherent in collective research methodologies, such as the one followed here, is not greater than in any other qualitative inquiry methodology, where the following paradox is largely observed. On the one hand, under a critical paradigm perspective, 'the intent of the process is to respect and support participants in a study, not further marginalize them' (Creswell and Miller 2000: 128), and therefore engaging participants as co-researchers is a positive aspect that adds to the study's validity, as it allows participants to build their views into the study. On the other hand, as it is always difficult for researchers to 'self-disclose their assumptions, beliefs, and biases' (Creswell and Miller 2000: 127); a certain reflexivity is always necessary for researchers to acknowledge a socio-historico-political situation that frames their positioning and interpretations.

Following the rationale above, a limitation of our study is the origin of all four experts from rich parts of the world (i.e. Switzerland, Canada, Australia and North of Spain), where certain expectations from teachers and learners are well-defined and certain infrastructures exist that render such expectations reasonable. Although all experts were carefully selected with experience criteria that transcend socio-economic barriers (e.g. all of them reported working experience in the Global South), the limitation of constructing a monofocal lens of looking at education reality is still present.

A last consideration has to do with the 'lessons learnt' from this collective research experience and how they can impact research and practice beyond the Covid-19 crisis. While the origin of this paper is to be found in the reaction to the Covid-19 pandemic, of course it arrives somewhat too late. As we write, most universities have found their way of teaching online and will not be able to draw from the insights presented in this paper (along with many others) to develop their response to the emergency. Nonetheless, while things are settling back to (an either 'old' or 'new') normal at least in our countries, the worst thing that could happen is not learning from the crisis we experienced. In the hustle of the emergency, many decisions at institutional and personal level were taken, and many practices changed, but little time was devoted to reflection-in-action (Schön 1983). We hope that we can now find time for reflection-on-action, and we hope that this paper provides some useful signposts and scaffolds to guide it.

The outcomes of such a reflection about the design, teacher presence and assessment in online learning, form the basis of a pedagogical preparation for a potential strike back of the virus, or for any other situation that will lead us to a new lock-down. Under this respect, the current pandemic can be understood as a catalyst that highlighted the need for educational change towards more flexible models and practices that best respond to the complexity and unpredictability of today's fast and interconnected but and still fragile society.

\section{Conclusion}

We will conclude with a quotation by Kirschner:

if one looks at teaching as a profession based upon a 'combination of complex cognitive and higher-order skills, highly integrated knowledge structures, 
interpersonal and social skills, and attitudes and values' (Van Merriënboer \& Kirschner), the TEL distinction need not be made. Teachers need to receive training in how to apply what they have learnt 'in a variety of situations (transfer) and over an unlimited time span (lifelong learning)'. TEL is simply the newest tool on the horizon. (Kirschner 2015: 312).

By claiming that we should not be talking about 'new' learning, 'what we should be talking about is effective, efficient and enjoyable learning that is facilitated and/or enhanced by the technologies available to the teacher, the learner and the school' (Kirschner 2015: 313).

On the one hand, the design of effective learning environments and embedding online technologies can serve as catalysts for teachers to experiment new things, explore creative alternatives and reflect on their own practices (Goodyear and Markauskaite 2009; McKenney et al. 2015). On the other hand, the mandate for quality teaching at higher education institutions, followed by adequate teaching evaluation methods, is nowadays more urgent than before, as the post-pandemic numbers of foreign and overseas students' subscriptions in the majority of universities have dramatically dropped (Altbach and De Wit 2020). For higher education institutions around the world to be competitive (again), evidence of faculty preparedness in terms of professionalism is necessary. Online teaching is an essential part of such professional preparedness but not the only one. Universities, now more than ever, should invest in teacher professional development of their faculty, for them to be updated on effective pedagogical methods with or without the use of online technologies.

Funding Information Chrysi Rapanta received national funds through the FCT-Fundação para a Ciência e a Tecnologia, I.P., under the Norma Transitória-DL 57/2016/CP1453/CT0066. Peter Goodyear received funding from the Australian Research Council under grant DP150104163.

\section{Compliance with Ethical Standards}

Conflict of Interest The authors declare that they have no conflict of interest.

\section{References}

Altbach, P. G., \& De Wit, H. (2020). Postpandemic outlook for higher education is bleakest for the poorest. International Higher Education, 102, 3-5.

Anderson, T. (2003). Modes of interaction in distance education: recent developments and research questions. In M. G. Moore \& W. G. Anderson (Eds.), Handbook of distance education (pp. 155-170). New Jersey: Lawrence Erlbaum Associates.

Anderson, T. (2011a). Towards a theory of online learning. In T. Anderson (Ed.), The theory and practice of online learning. 2nd Edition (pp. 45-74). Edmonton: Athabasca University Press.

Anderson, T. (2011b). Teaching in an online learning context. In T. Anderson (Ed.), The theory and practice of online learning. 2nd Edition (pp. 343-366). Edmonton: Athabasca University Press.

Anderson, T., Rourke, L., Garrison, D. R., \& Archer, W. (2001). Assessing teaching presence in a computer conferencing context. Journal of Asynchronous Learning Networks, 5(2), 1-17. https://doi.org/10.24059 /olj.v5i2.1875.

Angeli, C., \& Valanides, N. (2005). Preservice elementary teachers as information and communication technology designers: an instructional systems design model based on an expanded view of pedagogical 
content knowledge. Journal of Computer Assisted Learning, 21(4), 292-302. https://doi.org/10.1111 j.1365-2729.2005.00135.x.

Bach, S., Haynes, P., \& Smith, J. L. (2007). Online learning and teaching in higher education. Maidenhead: Open University Press.

Bakhtin, M. M. (1986). Speech genres and other late essays. Austin: University of Texas Press.

Banks, S., Goodyear, P., Hodgson, V., \& McConnell, D. (2003). Introduction to the special issue on advances in research on networked learning. Instructional Science, 31, 1-6.

Bates, A. W. (2019). Teaching in a digital age. 2nd Edition. Vancouver: Tony Bates Associates. https://pressbooks.bccampus.ca/teachinginadigitalagev2/. Accessed 15 June 2020.

Bates, A. W. (2020). Advice to those about to teach online because of the corona-virus. 9 March. https://www. tonybates.ca/2020/03/09/advice-to-those-about-to-teach-online-because-of-the-corona-virus/ . Accessed 30 April 2020.

Bates, A. W., \& Poole, G. (2003). Effective teaching with technology in higher education. San Francisco: Jossey-Bass.

Bayne, S. (2015). What's the matter with 'technology-enhanced learning'? Learning, Media and Technology, 40(1), 5-20. https://doi.org/10.1080/17439884.2014.915851.

Bogner, A., Littig, B., \& Menz, W. (2009). Introduction: expert interviews - an introduction to a new methodological debate. In A. Bogner, B. Littig, \& W. Menz (Eds.), Interviewing experts (pp. 1-16). London: Palgrave Macmillan.

Botturi, L., \& Del Percio, M. (2007). Involvement, institutional roles, and design models in e-learning. In U. Bernath \& A. Sangrà (Eds.), Research on competence development in online distance education and elearning - selected papers from the 4th EDEN Research Workshop in Castelldefels/Spain, October 2528, 2006 (pp. 171-187). Oldenburg: BIS-Verlag, ASF series.

Bullen, M., \& Janes, D. P. (2007). Making the transition to E-learning: strategies and issues. Hershey: Information Science Publishing.

Carr-Chellman, A. (2016). Instructional design for teachers: improving classroom practice. 2nd Edition. London: Routledge.

Carr-Chellman, A., \& Duchastel, P. (2000). The ideal online course. British Journal of Educational Technology, 31(3), 229-241. https://doi.org/10.1111/1467-8535.00154.

Ching, Y.-H., Hsu, Y.-C., \& Baldwin, S. (2018). Becoming an online teacher: an analysis of prospective online instructors' reflections. Journal of Interactive Learning Research, 29(2), 145-168. https://doi. org/10.24059/olj.v22i2.1212.

Cho, M. H., \& Shen, D. (2013). Self-regulation in online learning. Distance Education, 34(3), $290-301$. https://doi.org/10.1080/01587919.2013.835770.

Creswell, J. W., \& Miller, D. L. (2000). Determining validity in qualitative inquiry. Theory Into Practice, 39(3), 124-130. https://doi.org/10.1207/s15430421tip3903 2.

Crisp, G., Guàrdia, L., \& Hillier, M. (2016). Using e-Assessment to enhance student learning and evidence learning outcomes. International Journal of Educational Technology in Higher Education, 13(1), Art. 18. https://doi.org/10.1186/s41239-016-0020-3.

De Laat, M., Lally, V., Lipponen, L., \& Simons, R.-J. (2007). Online teaching in networked learning communities: a multi-method approach to studying the role of the teacher. Instructional Science, 35(3), 257-286. https://doi.org/10.1007/s11251-006-9007-0.

Fawns, T. (2019). Postdigital education in design and practice. Postdigital Science and Education, 1(1), 132145. https://doi.org/10.1007/s42438-018-0021-8.

Garrison, D. R., \& Kanuka, H. (2004). Blended learning: uncovering its transformative potential in higher education. The Internet and Higher Education, 7(2), 95-105. https://doi.org/10.1016/j. iheduc.2004.02.001.

Geist, M. (2019). More steps needed: government commissioned report shows Canadian wireless pricing remains among highest in the developed world. Michael Geist blog. http://www.michaelgeist.ca/2019/01 /more-steps-needed-government-commissioned-report-shows-canadian-wireless-pricing-remains-amonghighest-in-the-developed-world/. Accessed 30 April 2020.

Gonzalez, C. (2009). Conceptions of, and approaches to, teaching online: a study of lecturers teaching postgraduate distance courses. Higher Education, 57(3), 299-314. https://doi.org/10.1007/s10734-0089145-1.

Goodyear, P. (2002). Teaching online. In N. Hativa \& P. Goodyear (Eds.), Teacher thinking, beliefs and knowledge in higher education (pp. 79-101). Dordrecht: Kluwer Academic Publishers.

Goodyear, P. (2015). Teaching as design. Herdsa Review of Higher Education, 2(2), 27-50. https://doi. org/10.1111/hea.12037_26. 
Goodyear, P., \& Dimitriadis, Y. (2013). In medias res: reframing design for learning. Research in Learning Technology, 21. https://journal.alt.ac.uk/index.php/rlt/article/view/1391. Accessed 15 June 2020.

Goodyear, P., \& Markauskaite, L. (2009). Teachers' design knowledge, epistemic fluency and reflections on students' experiences. In Paper presented at the Higher Education Research and Development Society of Australasia (HERDSA) conference. Darwin: Australia.

Guàrdia, L. (coord.), Witthauss, G., Padilla, B., Guàrdia, L., \& Girona, C. (2016). Next generation pedagogy: IDEAS for online and blended higher education. Barcelona: Universitat Oberta de Catalunya. http://openaccess.uoc.edu/webapps/o2/bitstream/10609/51441/1/Next_Generation_Pedagogy.pdf. Accesseed 15 June 2020.

Guàrdia, L., \& Maina, M. (2018). FUTURA - next generation pedagogy. IDEAS for online and blended higher education. EADT Envisioning Report, 2, 28-30 http://empower.eadtu.eu/images/report/The Envisioning_Report_for_Empowering_Universities_2nd_edition_2018.pdf. Accesseed 15 June 2020.

Guàrdia, L., Maina, M., \& Sangrà, A. (2013). MOOC design principles: a pedagogical approach from the learner's perspective. eLearning papers, 33, 1-6 https://r-libre.teluq.ca/596/1/In-depth_33_4.pdf. Accesseed 15 June 2020.

Henderson, S., \& Gilding, M. (2004). 'I've never clicked this much with anyone in my life': trust, and hyperpersonal communication in online friendship. New Media \& Society, 6(4), 487-506. https://doi. org/10.1177/146144804044331.

Hodge, R. (2020). Using zoom while working from home? Here are the privacy risks to watch out for. CNET, 2 April. https://www.cnet.com/news/using-zoom-while-working-from-home-here-are-the-privacy-risksto-watch-out-for/. Accessed 30 April 2020.

Hodges, C., Moore, S., Lockee, B., Trust, T., \& Bond, A. (2020). The difference between emergency remote teaching and online learning. Educause Review, 27 March. https:/er.educause.edu/articles/2020/3/thedifference-between-emergency-remote-teaching-and-online-learning. Accessed 15 June 2020.

Houlden, S., \& Veletsianos, G. (2020). Coronavirus pushes universities to switch to online classes - but are they ready?. The Conversation, 12 March. https://theconversation.com/coronaviruspushes-universities-toswitch-to-online-classes-but-arethey-ready-132728. Accesseed 15 June 2020.

Houston, D., Meyer, L. H., \& Paewai, S. (2006). Academic staff workloads and job satisfaction: expectations and values in academe. Journal of Higher Education Policy and Management, 28(1), 17-30. https://doi. org/10.1080/13600800500283734.

Jandrić, P. (2017). Learning in the age of digital reason. Rotterdam: Sense.

Jandrić, P. (2020). Postdigital research in the time of Covid-19. Postdigital Science and Education, 2(2), 233238. https://doi.org/10.1007/s42438-020-00113-8.

Jandrić, P., Ryberg, T., Knox, J., Lacković, N., Hayes, S., Suoranta, J., Smith, M., Steketee, A., Peters, M. A., McLaren, P., Ford, D. R., Asher, G., McGregor, C., Stewart, G., Williamson, B., \& Gibbons, A. (2019). Postdigital dialogue. Postdigital Science and Education, 1(1), 163-189. https://doi.org/10.1007/s42438018-0011-X.

Kali, Y., Goodyear, P., \& Markauskaite, L. (2011). Researching design practices and design cognition: contexts, experiences and pedagogical knowledge-in-pieces. Learning, Media and Technology, 36(2), 129-149. https://doi.org/10.1080/17439884.2011.553621.

Kirkwood, A., \& Price, L. (2014). Technology-enhanced learning and teaching in higher education: what is 'enhanced' and how do we know? A critical literature review. Learning, Media and Technology, 39(1), 6-36. https://doi.org/10.1080/17439884.2013.770404.

Kirschner, P. A. (2015). Do we need teachers as designers of technology enhanced learning? Instructional Science, 43(2), 309-322. https://doi.org/10.1007/s11251-015-9346-9.

Laurillard, D., \& Masterman, E. (2010). TPD as online collaborative learning for innovation in teaching. In J. O. Lindberg \& A. D. Olofsson (Eds.), Online learning communities and teacher professional development: methods for improved education delivery (pp. 230-246). Hershey: IGI Global.

Matusov, E., Marjanovic-Shane, A., \& Gradovski, M. (2019). Dialogic pedagogy and polyphonic research art: Bakhtin by and for educators. New York: Palgrave McMillan.

McKenney, S., Kali, Y., Markauskaite, L., \& Voogt, J. (2015). Teacher design knowledge for technology enhanced learning: an ecological framework for investigating assets and needs. Instructional Science, 43(2), 181-202. https://doi.org/10.1007/s11251-014-9337-2.

Moallem, M. (1998). An expert teacher's thinking and teaching and instructional design models and principles: an ethnographic study. Educational Technology Research and Development, 46(2), 37-64. https://doi.org/10.1007/bf02299788.

Moore, M. G. (1991). Editorial: Distance education theory. The American Journal of Distance Education, 5(3), 1-6. https://doi.org/10.1080/08923649109526758.

Moustakas, C. (1994). Phenomenological research methods. Thousand Oaks: Sage. 
Munoz, A., \& Mackay, J. (2019). An online testing design choice typology towards cheating threat minimisation. Journal of University Teaching \& Learning Practice, 16(3). https://ro.uow.edu. au/jutlp/vol16/iss3/5. Accessed 15 June 2020.

Nilson, L. B., \& Goodson, L. A. (2017). Online teaching at its best: merging instructional design with teaching and learning research. San Francisco: Jossey-Bass.

Norris, J., Sawyer, R. D., \& Lund, D. (Eds.). (2012). Duoethnography: dialogic methods for social, health, and educational research. Walnut Creek: Left Coast Press.

Ocak, M. A. (2011). Why are faculty members not teaching blended courses? Insights from faculty members. Computers \& Education, 56(3), 689-699. https://doi.org/10.1016/j.compedu.2010.10.011.

Parchoma, G., Koole, M., Morrison, D., Nelson, D., \& Dreaver-Charles, K. (2019). Designing for learning in the yellow house: a comparison of instructional and learning design origins and practices. Higher Education Research \& Development, 1-16. https://doi.org/10.1080/07294360.2019.1704693.

Picciano, A. G. (2017). Theories and frameworks for online education: Seeking an integrated model. Online Learning, 21(3), 166-190. https://doi.org/10.24059/olj.v21i3.1225.

Richey, R. C., Klein, J. D., \& Tracey, M. W. (2011). The instructional design knowledge base: theory, research, and practice. New York: Routledge.

Schön, D. (1983). The reflective practitioner: how professionals think in action. London: Temple Smith.

Shor, I., \& Freire, P. (1987). A pedagogy for deliberation: dialogues on transforming education. Westport: Bergin \& Garvey Publishers.

Shulman, L. (1987). Knowledge and teaching: foundations of the new reform. Harvard Educational Review, $57,1-22$.

Sims, R. (2015). Revisiting "beyond instructional design”. Journal of Learning Design, 8(3), $29-41$. https://doi.org/10.5204/jld.v8i3.252.

Tennyson, R. D., \& Breuer, K. (2010). Psychological foundations for instructional design theory. In R. D. Tennyson, F. Schott, N. M. Seel, \& S. Dijkstra (Eds.), Instructional design: international perspectives, Theory, research and models, Vol. 1 (pp. 113-134). New York: Routledge.

Tennyson, R. D., \& Schott, F. (2010). Instructional design theory, research, and models. In R. D. Tennyson, F. Schott, N. M. Seel, \& S. Dijkstra (Eds.), Instructional design: international perspectives, Theory, research and models, Vol. 1 (pp. 1-18). New York: Routledge.

Winters, N., \& Mor, Y. (2008). IDR: a participatory methodology for interdisciplinary design in technology enhanced learning. Computers \& Education, 50(2), 579-600. https://doi.org/10.1016/j. compedu.2007.09.015.

World Health Organization (n.d.). Coronavirus disease (COVID-19) pandemic. https://www.who. int/emergencies/diseases/novel-coronavirus-2019. Accessed 15 June 2020. 